\title{
Evidence Base for Restrictive Transfusion Triggers in High-Risk Patients
}

\author{
Donat R. Spahn Gabriela H. Spahn Philipp Stein \\ Institute of Anesthesiology, University and University Hospital of Zurich, Zurich, Switzerland
}

\section{Keywords}

Red blood cell transfusions - Blood transfusion . Transfusion trigger . Patient blood management

\section{Summary}

Liberal versus restrictive red blood cell (RBC) transfusion triggers have been debated for years. This review illustrates the human body's physiologic response to acute anemia and summarizes the evidence from prospective randomized trials (RCTs) for restrictive use of RBC transfusions in high-risk patients. During progressive anemia, the human body maintains the oxygen delivery to the tissues by an increase in cardiac output and peripheral oxygen extraction. Seven RCTs with a total of 5,566 highrisk patients compared a restrictive hemoglobin $(\mathrm{Hb})$ transfusion trigger $(\mathrm{Hb}<70$ or $<80 \mathrm{~g} / \mathrm{l})$ with a liberal $\mathrm{Hb}$ transfusion trigger $(\mathrm{Hb}<90$ or $<100 \mathrm{~g} / \mathrm{l})$. Unanimously these studies show non-inferiority, safety, and a significant reduction in $\mathrm{RBC}$ transfusions in the restrictive groups. In one RCT mortality was higher in the liberal $\mathrm{Hb}$ transfusion group, and in two additional RCTs mortality of subgroups or after risk adjustment was significantly higher in the liberal $\mathrm{Hb}$ transfusion trigger groups. Conclusion: Strong RCT evidence suggests the safety of restrictive transfusion triggers. As a consequence, an $\mathrm{Hb}$ transfusion trigger of $<70 \mathrm{~g} / \mathrm{l}$ is recommended for highrisk patients.

\section{Introduction}

Red blood cell (RBC) transfusions are widely used worldwide in primary health care in less developed and newly industrialized countries as well as for high-performance procedures in health care of high-income countries. Improved survival due to RBC transfusions has been shown in specific situations such as in severe malaria-induced anemia in children with a hemoglobin $(\mathrm{Hb})$ concentration of $<39 \mathrm{~g} / \mathrm{l}$ or an $\mathrm{Hb}<47 \mathrm{~g} / \mathrm{l}$ with concomitant respiratory distress [13]. RBC transfusions also improve survival of elderly patients undergoing noncardiac surgery with a preoperative $\mathrm{Hb}<80 \mathrm{~g} / \mathrm{l}$ [4]. In addition, the European Trauma Treatment Guidelines recommend maintaining an $\mathrm{Hb}$ level of 70-90 g/l in severely injured patients by cell salvage, if possible, and RBC transfusions, if necessary [5].

However, RBC transfusions have also been shown to result in an increased mortality, length of hospital stay, organ dysfunction (lung, kidney, heart), infections, transfusion reactions, and huge costs $[6,7]$. Therefore, a targeted use of RBC transfusion is mandatory, including evidence-based $\mathrm{RBC}$ transfusion triggers.

Defining the critical transfusion trigger in patients is not trivial. However, understanding the underlying physiological response and compensatory mechanisms during progressive anemia may be one approach to find the critical $\mathrm{Hb}$ level at which a $\mathrm{RBC}$ transfusion would be necessary to avoid organ dysfunction or whole organism damage [8]. Another approach is to analyze outcome studies assessing the impact of different $\mathrm{Hb}$ transfusion triggers on clinically relevant outcomes such as mortality, morbidity, and the need for advanced life support. In this review we limit our analysis for both approaches to adult patients.

Last but not least only focusing on $\mathrm{Hb}$ transfusion triggers is an insufficient approach to the problems of RBC transfusion, patient safety, and outcome. The more holistic approach to patient safety and outcome is the concept of patient blood management which aims at improving outcome by correcting the three main factors resulting in adverse patient outcome, i.e., preoperative anemia $[9$, $10]$, perioperative $\mathrm{RBC}$ loss $[11,12]$, and $\mathrm{RBC}$ transfusions $[6,13]$.

\section{KARGER \\ Fax +497614520714

Prof. Dr. med. Donat R. Spahn, FRCA 


\section{Physiology of Progressive Anemia}

Oxygen delivery and off-loading to the tissues is vital for our organism to maintain energy production by oxidation of glucose to carbon dioxide and water. In the mitochondria stepwise metabolism of the glucose molecule leads to the production of adenosine triphosphate (ATP). ATP hydrolysis to adenosine diphosphate by ATPases is an ubiquitary process to sustain cellular enzyme energy requirements. In aerobic conditions, one glucose molecule is metabolized to 30 molecules of ATP, whereas in anaerobic or hypoxic circumstances the glucose degradation stops at the level of 3 carbon atoms with lactate as an end product, resulting in an overall gain of 2 molecules of ATP only.

Oxygen delivery $\left(\mathrm{DO}_{2}\right)$ is the product of cardiac output and arterial oxygen content $\left(\mathrm{CaO}_{2}\right) \cdot \mathrm{CaO}_{2}$ is the sum of $\mathrm{Hb}$-bound oxygen $\left(\mathrm{Hb} \times 1.34 \times \mathrm{SaO}_{2}\right)$ and plasma-dissolved oxygen $\left(\mathrm{PaO}_{2} \times \mathrm{F}\right.$; $\mathrm{F}=0.0031$ if $\mathrm{PaO}_{2}$ is in $\mathrm{mm} \mathrm{Hg}, \mathrm{F}=0.0233$ if $\mathrm{PaO}_{2}$ is in $\mathrm{kPa}$ ), whereby under atmospheric conditions the $\mathrm{Hb}$-bound part is far greater (approximately 98\%) than the plasma-dissolved part [8].

Therefore, oxygen delivery depends critically on cardiac output, $\mathrm{Hb}$ concentration, and $\mathrm{SaO}_{2}$. Hence tissue hypoxia (insufficient oxygen delivery) can be due to ischemia (reduction in cardiac output or blood supply), hypoxia (decrease of $\mathrm{SaO}_{2}$ ), toxins (blocking $\mathrm{Hb}$ oxygen binding), and anemia.

Blood loss and concomitant crystalloid or colloid infusion results in normovolemic hemodilution, i.e. normovolemia with a decreased $\mathrm{Hb}$ concentration. Physiologically, cardiac output increases to compensate the lower $\mathrm{CaO}_{2}$ at low $\mathrm{Hb}$ concentrations in order to maintain oxygen delivery. The increase in cardiac output is primarily due to an increase in stroke volume and inotropy and only secondarily due an increase in heart rate. $\mathrm{O}_{2}$ extraction increases simultaneously favoring $\mathrm{O}_{2}$ off-loading to the tissue. During extreme anemia and hemorrhagic shock, cardiac output is additionally redistributed to preserve blood and oxygen delivery to the vital organs (heart and brain) [14].

When hemoglobin concentration is lowered to a critical value $\mathrm{Hb}$ (crit), $\mathrm{O}_{2}$ off-loading to the tissue is no more sufficient to maintain $\mathrm{O}_{2}$ consumption. The $\mathrm{Hb}$ (crit) can be experimentally determined by measuring the start of the decline of whole body or organ oxygen uptake. As a consequence and without further treatment, animals die within $3 \mathrm{~h}$ after reaching the $\mathrm{Hb}$ (crit) [15]. By increasing the inspired $\mathrm{O}_{2}$ concentration, an exaggerated level of hemodilution with a lower $\mathrm{Hb}$ (crit) can be reached [16].

Acute anemia tolerance differs among organs. In anesthetized pigs, cellular signs of hypoxia in the kidney and skeletal muscle developed at significantly higher $\mathrm{Hb}$ concentrations than in the heart, brain, and liver [17]. Last but not least, anesthetic measures such as deep neuromuscular blockade [18], application of norepinephrine to treat severe arterial hypotension [19], and induction of hypothermia [20] can increase anemia tolerance. From a physiologic point of view, anemia tolerance thus is quite remarkable. Interestingly, the human body responds very similarly, and its compensatory capacity is largely maintained even in patients with cardiovascular diseases and also in the elderly $[8,14]$.

\section{Prospective Randomized Studies on the Effect of Restrictive versus Liberal Hemoglobin Transfusion Triggers}

The first prospective randomized study compared the effect of an $\mathrm{Hb}$ transfusion trigger of $<70 \mathrm{~g} / \mathrm{l}$ with that of a transfusion trigger of $<90 \mathrm{~g} / \mathrm{l}$ in general intensive care unit (ICU) patients $(\mathrm{n}=$ 838) [21]. 30-day mortality was not significantly different between the groups, but there was a trend $(\mathrm{p}=0.10)$ towards better survival in the restrictive group. In two prospectively defined subgroups, in patients younger than 55 years and in patients with APACHE II scores of $\leq 20$, however, survival was significantly better in the restrictive transfusion groups. In addition, hospital mortality was lower in the restrictive group (22.2 vs. $28.1 \%$; $\mathrm{p}=0.05)$, and there was significantly less multiple organ dysfunction in the restrictive versus the liberal RBC transfusion group [21].

In the next prospective randomized study, the effect of an $\mathrm{Hb}$ transfusion trigger of $<80 \mathrm{~g} / \mathrm{l}$ was compared with that of a transfusion trigger of $<100 \mathrm{~g} / \mathrm{l}$ in patients $(\mathrm{n}=502)$ undergoing cardiac surgery [22]. Primary outcome, a composite of mortality and major morbidity (cardiogenic shock, acute respiratory distress syndrome, or acute renal injury requiring renal replacement), was similar in both groups. However, when analyzed independently of group assignment, each RBC transfusion significantly increased the risk of 30 -day mortality or clinical complications by $20 \%$ (hazard ratio $1.2,95 \%$ CI 1.1-1.4; $\mathrm{p}=0.002$ ).

Also in elderly high-risk patients $(n=2,016)$ with hip fracture and signs of coronary artery disease and a postoperative $\mathrm{Hb}<100$ $\mathrm{g} / \mathrm{l}$, the effect of a liberal $\mathrm{Hb}$ transfusion trigger of $<100 \mathrm{~g} / \mathrm{l}$ was compared with a restrictive transfusion trigger (combination of well-defined symptoms of anemia or an $\mathrm{Hb}<80 \mathrm{~g} / \mathrm{l}$ ) in a prospective randomized study [23]. 60-day mortality was similar in the restrictive $(6.6 \%)$ and the liberal group (7.6\%), and also the inability to walk was similar between the groups. The authors subsequently analyzed long-term survival over a median of 3 years. There were 432 deaths in the liberal group and 409 deaths in the restrictive group (hazard ratio $1.09,95 \%$ CI $0.95-1.25 ; \mathrm{p}=0.21$ ). In only 1 of 18 subgroup analyses there was a trend $(\mathrm{p}<0.10)$ towards a higher or lower mortality in patients randomized to the liberal $\mathrm{Hb}$ transfusion trigger. Interestingly, a trend towards a higher mortality was observed in patients with coronary artery disease randomized to the liberal $\mathrm{Hb}$ transfusion trigger (hazard ratio 1.26, 95\% CI 1.04$1.54 ; \mathrm{p}=0.06)$. Causes of death did not differ between groups $(\mathrm{p}=0.99)[24]$.

In patients $(\mathrm{n}=912)$ with acute upper gastrointestinal bleeding, the effect of an $\mathrm{Hb}$ transfusion trigger of $<70 \mathrm{~g} / \mathrm{l}$ was compared with that of an $\mathrm{Hb}$ transfusion trigger of $<90 \mathrm{~g} / \mathrm{l}$ in a prospective randomized fashion [25]. 45-day survival was significantly better in the restrictive (95\%) than in the liberal group (91\%), with a hazard ratio for death of 0.55 (95\% CI 0.33-0.92; $\mathrm{p}=0.02)$ favoring the restrictive $\mathrm{RBC}$ transfusion regimen. In addition, the rate of rebleeding was significantly lower in the restrictive than in the liberal group ( 10 vs. $16 \% ; \mathrm{p}=0.01$ ); moreover, less emergency surgery was required ( 2 vs. $6 \% ; \mathrm{p}=0.04$ ), complication rate was lower (40 vs. 
Table 1. Prospective randomized studies on the effect of restrictive versus liberal hemoglobin transfusion triggers

\begin{tabular}{|c|c|c|c|c|}
\hline & Study population & Leukoreduction & $\begin{array}{l}\text { Storage duration } \\
\text { (median), days }\end{array}$ & $\mathrm{RBC}$ transfusion before enrollment \\
\hline Hébert et al. 1999 [21] & $\begin{array}{l}\text { general ICU } \\
(\mathrm{n}=838)\end{array}$ & no & unknown & $\begin{array}{l}2.5 \mathrm{U} / \text { patient (restrictive) } \\
2.3 \mathrm{U} / \text { patient (liberal) }\end{array}$ \\
\hline Hajjar et al. 2010 [22] & $\begin{array}{l}\text { cardiac surgery } \\
(\mathrm{n}=502)\end{array}$ & no & 3 & none \\
\hline Carson et al. 2011 [23] & $\begin{array}{l}\text { hip fracture } \\
(\mathrm{n}=2,016)\end{array}$ & $90 \%$ & 22 & $\begin{array}{l}1.8 \mathrm{U} / \text { transfused patient (restrictive) } \\
1.8 \mathrm{U} / \text { transfused patient (liberal) }\end{array}$ \\
\hline Villanueva et al. 2013 [25] & $\begin{array}{l}\text { upper GI bleeding } \\
(\mathrm{n}=912)\end{array}$ & $100 \%$ & 15 & none \\
\hline Walsh et al. 2013 [26] & $\begin{array}{l}\text { mechanical ventilation } \\
(\mathrm{n}=100)\end{array}$ & no & 21 & $\begin{array}{l}71 \% \text { with a median of } 3 \mathrm{U} / \text { patient (restrictive) } \\
67 \% \text { with a median of } 2 \mathrm{U} / \text { patient (liberal) }\end{array}$ \\
\hline Robertson et al. 2014 [27] & $\begin{array}{l}\text { traumatic brain injury } \\
(\mathrm{n}=200)\end{array}$ & $100 \%$ & unknown & none \\
\hline Holst et al. 2014 [28] & $\begin{array}{l}\text { septic shock } \\
(\mathrm{n}=998)\end{array}$ & $100 \%$ & unknown & $\begin{array}{l}10 \% \text { with a median of } 2 \mathrm{U} / \text { transfused patient (restrictive) } \\
12 \% \text { with a median of } 2 \mathrm{U} / \text { transfused patient (liberal) }\end{array}$ \\
\hline
\end{tabular}

$48 \% ; \mathrm{p}=0.02)$ and length of hospital stay was shorter (9.6 vs. 11.5 days; $\mathrm{p}=0.01$ ) in the restrictive versus the liberal group.

In a feasibility study including 100 patients, Walsh et al. [26] studied the effect of a restrictive $\mathrm{Hb}$ transfusion trigger $(\mathrm{Hb}<70$ $\mathrm{g} / \mathrm{l})$ vs. a liberal $\mathrm{Hb}$ transfusion trigger $(\mathrm{Hb}<90 \mathrm{~g} / \mathrm{l})$ in patients older than 55 years who were ventilated mechanically for at least 4 days in the ICU. The Hb level was significantly different between the groups during the study period of 14 days ( $\mathrm{Hb}$ difference $=14$ $\mathrm{g} / \mathrm{l}, 95 \% \mathrm{CI} 1.2-1.6 \mathrm{~g} / \mathrm{l} ; \mathrm{p}<001)$. Fewer patients $(-22 \%)$ randomized to the restrictive group were transfused and received a median of 1 RBC transfusions less $(p=0.002)$. Ventilation-free days tended to be higher (38 days) in the restrictive group than in the liberal group (27 days), and also 180-day mortality tended to be lower in the restrictive group (37\%) when compared to the liberal group (55\%). While these differences did not reach statistical significance, this study clearly shows that a liberal transfusion regimen did not facilitate weaning nor influenced mortality favorably.

Recently the effect of erythropoietin (yes/no) and Hb transfusion trigger $(\mathrm{Hb}<70 \mathrm{~g} / \mathrm{l}$ vs. $\mathrm{Hb}<100 \mathrm{~g} / \mathrm{l})$ was compared in a prospective randomized factorial design $(2 \times 2)$ study in patients $(\mathrm{n}=200)$ with acute traumatic brain injury [27]. The primary outcome was favorable neurologic outcome as assessed by the Glasgow Outcome Score at 6 months. Multiple secondary outcomes were also assessed prospectively. The administration of erythropoietin did not affect any outcome, and there was also no interaction between erythropoietin administration and the $\mathrm{Hb}$ transfusion levels. Glasgow Outcome Score at 6 months was similar in both transfusion groups, but disability tended to be less ( 5 vs. $8 ; \mathrm{p}=$ $0.06)$ in the restrictive vs. the liberal group, and there were fewer thrombotic complications in the restrictive vs. the liberal group (8 vs. $22 \% ; \mathrm{p}=0.009$ ).
Last but not least, the effect of a restrictive $(\mathrm{Hb}<70 \mathrm{~g} / \mathrm{l})$ vs. a liberal $(\mathrm{Hb}<90 \mathrm{~g} / \mathrm{l})$ transfusion regimen on outcome of patients ( $\mathrm{n}=998)$ with septic shock has been compared in a prospective randomized study [28]. The primary outcome was 90 -day mortality; secondary outcome was the need for advanced support measures (vasopressors, inotropes, mechanical ventilation, and renalreplacement therapies) within the first 28 days. Mortality and the need for advanced support measures were similar between both groups.

Interestingly, in all studies mentioned in this section, the lack of efficacy and the side effect profile of liberal transfusion regimens do not appear to be related to the populations studied, irrespective of the facts whether leukoreduced or non-leukoreduced RBCs were transfused, how long the RBCs were stored before use (where this information is available), or whether RBCs had been transfused prior to study enrollment or not (table 1).

\section{Meta-Analyses}

There are two important meta-analyses that need to be presented here. In 2012 Carson et al. [29] analyzed 19 prospective randomized trials comparing restrictive and liberal transfusion regimens, including a total of 6,264 patients. This meta-analysis clearly showed that a restrictive transfusion regimen reduced the need for $\mathrm{RBC}$ transfusions by $39 \%$ (relative risk $0.61,95 \%$ CI $0.52-0.73$ ), hospital mortality by $23 \%$ (relative risk $0.77,95 \%$ CI $0.62-0.95$ ), and infections by $19 \%$ (relative risk $0.81,95 \%$ CI $0.66-1.00$ ). 30 day mortality $(-15 \%)$ just missed statistical significance (relative risk $0.85,95 \%$ CI $0.70-1.03$ ). However, the last 2 big prospective randomized studies in patients with upper gastrointestinal bleed- 
ing $(\mathrm{n}=912)$ and with septic shock $(\mathrm{n}=998)$ were not yet included, and since both had either a significant effect or a trend towards a better survival in the restrictive groups it may be expected that an updated meta-analysis including these two studies would show a long-term survival benefit for patients treated according to a restrictive transfusion regimen.

The second meta-analysis was performed in 2014 by Rohde et al. [30] including 18 prospective randomized studies with 7,593 patients. They found that a restrictive $\mathrm{RBC}$ transfusion regimen resulted in a reduction of postoperative infections by $12 \%$ (relative risk $0.88,95 \%$ CI $0.78-0.99 ; \mathrm{p}=0.033$ ) and of postoperative serious infections by $18 \%$ (relative risk $0.82,95 \%$ CI $0.72-0.95 ; \mathrm{p}=0.006$ ). Interestingly, when the meta-analysis was restricted to studies with only leukoreduced RBCs, the reduction of all types of infections decreased by $20 \%$ (relative risk $0.80,95 \%$ CI $0.67-0.95 ; \mathrm{p}=0.001$ ). This clearly shows that the infection risk due to RBC transfusion is neither eliminated nor reduced by leukoreduction.

\section{Hemoglobin Transfusion Trigger}

The combined evidence thus suggests that a liberal RBC transfusion regimen is not beneficial but potentially harmful for the patients. In high-risk patients, such as ICU patients, elderly patients with coronary artery disease, patients with upper gastrointestinal bleeding, patients with traumatic brain injury and patients with septic shock, an $\mathrm{Hb}$ transfusion trigger of $<70 \mathrm{~g} / \mathrm{l}$ is safe and helps avoiding transfusion-related complications. The $<70 \mathrm{~g} / \mathrm{l} \mathrm{Hb}$ transfusion trigger thus is established as the 'new normal' in all critical patients [31] with the potential exception of patients with an acute coronary syndrome in which an $\mathrm{Hb}$ transfusion trigger of $<80 \mathrm{~g} / \mathrm{l}$ might be adequate [32].

Remarkably, Goodnough et al. [33] succeeded in implementing a restrictive transfusion regimen in their center by an intelligent blood ordering system. The percentage of RBC transfusions at an $\mathrm{Hb}>80 \mathrm{~g} / \mathrm{l}$ thereby decreased from approximately 60 to below $30 \%$. In a subsequent study, Goodnough et al. [34] analyzed the effect of this change in transfusion policy on outcome and found a reduction of length of hospital stay from 10.1 to 6.2 days ( $\mathrm{p}<$ $0.001)$ and of mortality from 5.5 to $3.3 \%(\mathrm{p}<0.001)$ in transfused patients.

\section{Conclusion}

Compensatory mechanisms such as the increase of cardiac output and oxygen extraction allow the human body to tolerate low $\mathrm{Hb}$ values well. This compensatory capacity is largely maintained in patients with cardiovascular diseases and also in the elderly. Pro- spective randomized studies confirm this conclusion showing that liberal $\mathrm{Hb}$ transfusion regimens do not offer any outcome benefit to high-risk patients but in quite a number of situations inflict harm. Scientific evidence thus clearly mandates restrictive $\mathrm{Hb}$ transfusion triggers also for high-risk patients. Today the best investigated $\mathrm{Hb}$ transfusion trigger for high-risk patients is $<70 \mathrm{~g} / \mathrm{l}$.

\section{Disclosure Statement}

Donat R. Spahn's academic department is receiving grant support from the Swiss National Science Foundation, Berne, Switzerland; the Ministry of Health (Gesundheitsdirektion) of the Canton of Zurich, Switzerland, for Highly Specialized Medicine; the Swiss Society of Anesthesiology and Reanimation (SGAR), Berne, Switzerland; the Swiss Foundation for Anesthesia Research, Zurich, Switzerland; the Bundesprogramm Chancengleichheit, Berne, Switzerland; CSL Behring, Berne, Switzerland; and Vifor SA, Villars-sur-Glâne, Switzerland.

Donat R. Spahn was the chairman of the ABC Faculty and is the co-chairman of the ABC-Trauma Faculty, which both are managed by Physicians World Europe GmbH, Mannheim, Germany, and sponsored by unrestricted educational grants from Novo Nordisk Health Care AG, Zurich, Switzerland; CSL Behring GmbH, Marburg, Germany; and LFB Biomédicaments, Courtaboeuf Cedex, France.

In the past 5 years, Donat R. Spahn has received honoraria or travel support for consulting or lecturing from the following companies: Abbott AG, Baar, Switzerland; AMGEN GmbH, Munich, Germany; AstraZeneca AG, Zug, Switzerland; Bayer (Schweiz) AG, Zürich, Switzerland; Baxter AG, Volketswil, Switzerland; Baxter S.p.A., Roma, Italy; B. Braun Melsungen AG, Melsungen, Germany; Boehringer Ingelheim (Schweiz) GmbH, Basel, Switzerland; Bristol-Myers-Squibb, Rueil-Malmaison Cedex, France, and Baar, Switzerland; CSL Behring $\mathrm{GmbH}$, Hattersheim am Main, Germany, and Berne, Switzerland; $\mathrm{Cu}$ racyte AG, Munich, Germany; Ethicon Biosurgery, Sommerville, NJ, USA; Fresenius SE, Bad Homburg v.d.H., Germany; Galenica AG, Bern, Switzerland (including Vifor SA, Villars-sur-Glâne, Switzerland); GlaxoSmithKline GmbH \& Co. KG, Hamburg, Germany; Janssen-Cilag AG, Baar, Switzerland; JanssenCilag EMEA, Beerse, Belgium; Merck Sharp \& Dohme AG, Luzern, Switzerland; Novo Nordisk A/S, Bagsvärd, Denmark; Octapharma AG, Lachen, Switzerland; Organon AG, Pfäffikon/SZ, Switzerland; Oxygen Biotherapeutics, Costa Mesa, CA, USA; Photonics Healthcare GmbH, Munich, Germany; ratiopharm Arzneimittel Vertriebs-GmbH, Vienna, Austria; Roche Diagnostics International Ltd, Reinach, Switzerland; Roche Pharma (Schweiz) AG, Reinach, Switzerland; Schering-Plough International, Inc., Kenilworth, NJ, USA; Tem International GmbH, Munich, Germany; Verum Diagnostica GmbH, Munich, Germany; Vifor Pharma Deutschland GmbH, Munich, Germany; Vifor Pharma Österreich GmbH, Vienna, Austria; and Vifor (International) AG, St. Gallen, Switzerland.

Gabriela H. Spahn and Philipp Stein had no conflicts of interest to be declared.

Disclaimer in Relation to the Above Conflict-of-Interest Statement

None of the above listed companies and/or entities have been directly or indirectly involved in discussing and/or developing this manuscript or parts thereof. None of them have financially contributed to this endeavor in whatever form, neither directly or indirectly. Therefore, it is beyond my capacity to tell whether any of the above listed companies and/or entities do or do not have a direct financial interest in the subject matter or materials discussed in this manuscript. 


\section{References}

1 Lackritz EM, Campbell CC, Ruebush TK 2nd, Hightower AW, Wakube W, Steketee RW, Were JB: Effect of blood transfusion on survival among children in a Kenyan hospital. Lancet 1992;340:524-528.

2 English M, Ahmed M, Ngando C, Berkley J, Ross A: Blood transfusion for severe anaemia in children in a Kenyan hospital. Lancet 2002;359:494-495

3 Meremikwu M, Smith HJ: Blood transfusion for treating malarial anaemia. Cochrane Database Syst Rev 2000;2:CD001475

${ }_{4}$ Wu WC, Smith TS, Henderson WG, Eaton CB, Poses RM, Uttley G, Mor V, Sharma SC, Vezeridis M, Khuri SF, Friedmann PD: Operative blood loss, blood transfusion, and 30-day mortality in older patients after major noncardiac surgery. Ann Surg 2010;252:11-17.

5 Spahn DR, Bouillon B, Cerny V, Coats TJ, Duranteau J, Fernandez-Mondejar E, Filipescu D, Hunt BJ, Komadina R, Nardi G, Neugebauer E, Ozier Y, Riddez L, Schultz A, Vincent JL, Rossaint R: Management of bleeding and coagulopathy following major trauma: an updated European guideline. Crit Care 2013;17:R76.

6 Spahn DR, Goodnough LT: Alternatives to blood transfusion. Lancet 2013;381:1855-1865.

7 Shander A, Hofmann A, Ozawa S, Theusinger OM, Gombotz H, Spahn DR: Activity-based costs of blood transfusions in surgical patients at four hospitals. Transfusion 2010;50:753-765.

8 Madjdpour C, Spahn DR, Weiskopf RB: Anemia and perioperative red blood cell transfusion: a matter of tolerance. Crit Care Med 2006;34:S102-108.

9 Musallam KM, Tamim HM, Richards T, Spahn DR, Rosendaal FR, Habbal A, Khreiss M, Dahdaleh FS, Khavandi K, Sfeir PM, Soweid A, Hoballah JJ, Taher AT, Jamali FR: Preoperative anaemia and postoperative outcomes in non-cardiac surgery: a retrospective cohort study. Lancet 2011;378:1396-1407.

10 Baron DM, Hochrieser H, Posch M, Metnitz B, Rhodes A, Moreno RP, Pearse RM, Metnitz P; European Surgical Outcomes Study group for the Trials Groups of the European Society of Intensive Care Medicine; the European Society of Anaesthesiology: Preoperative anaemia is associated with poor clinical outcome in non-cardiac surgery patients. Br J Anaesth 2014;113:416-423.

- 11 Vivacqua A, Koch CG, Yousuf AM, Nowicki ER, Houghtaling PL, Blackstone EH, Sabik JF 3rd: Morbidity of bleeding after cardiac surgery: is it blood transfusion, reoperation for bleeding, or both? Ann Thorac Surg 2011;91:1780-1790.

12 Ranucci M, Baryshnikova E, Castelvecchio S, Pelissero G: Major bleeding, transfusions, and anemia: the deadly triad of cardiac surgery. Ann Thorac Surg 2013, 96:478-485.

13 Gombotz H: Patient blood management is key before elective surgery. Lancet 2011;378:1362-1363.

14 Klein HG, Spahn DR, Carson JL: Red blood cell transfusion in clinical practice. Lancet 2007:370:415-426.

15 Meier J, Kemming GI, Kisch-Wedel H, Wolkhammer S, Habler OP: Hyperoxic ventilation reduces 6-hour mortality at the critical hemoglobin concentration. Anesthesiology 2004;100:70-76.
6 Pape A, Steche M, Laout M, Wedel M, Schwerdel F, Weber CF, Zwissler B, Habler O: The limit of anemia tolerance during hyperoxic ventilation with pure oxygen in anesthetized domestic pigs. Eur Surg Res 2013; 51:156-169.

17 Lauscher P, Kertscho H, Schmidt O, Zimmermann R, Rosenberger P, Zacharowski K, Meier J: Determination of organ-specific anemia tolerance. Crit Care Med 2013;41:1037-1045.

18 Pape A, Kertscho H, Stein P, Lossen M, Horn O, Kutschker S, Zwissler B, Habler O: Neuromuscular blockade with rocuronium bromide increases the tolerance of acute normovolemic anemia in anesthetized pigs. Eur Surg Res 2012;48:16-25.

19 Meier J, Pape A, Loniewska D, Lauscher P, Kertscho H, Zwissler B, Habler O: Norepinephrine increases tolerance to acute anemia. Crit Care Med 2007;35:14841492.

20 McCullough JN, Zhang N, Reich DL, Juvonen TS, Klein JJ, Spielvogel D, Ergin MA, Griepp RB: Cerebral metabolic suppression during hypothermic circulatory arrest in humans. Ann Thorac Surg 1999;67: 1895-1899; discussion 1919-1921.

21 Hebert PC, Wells G, Blajchman MA, Marshall J, Martin C, Pagliarello G, Tweeddale M, Schweitzer I, Yetisir E: A multicenter, randomized, controlled clinical trial of transfusion requirements in critical care. Transfusion Requirements in Critical Care Investigators, Canadian Critical Care Trials Group. N Engl J Med 1999;340:409-417.

22 Hajjar LA, Vincent JL, Galas FR, Nakamura RE, Silva CM, Santos MH, Fukushima J, Kalil Filho R, Sierra DB, Lopes NH, Mauad T, Roquim AC, Sundin MR, Leao WC, Almeida JP, Pomerantzeff PM, Dallan LO, Jatene FB, Stolf NA, Auler JO Jr: Transfusion requirements after cardiac surgery: the TRACS randomized controlled trial. JAMA 2010;304:1559-1567.

23 Carson JL, Terrin ML, Noveck H, Sanders DW, Chaitman BR, Rhoads GG, Nemo G, Dragert K, Beaupre L, Hildebrand K, Macaulay W, Lewis C, Cook DR, Dobbin G, Zakriya KJ, Apple FS, Horney RA, Magaziner J: Liberal or restrictive transfusion in high-risk patients after hip surgery. N Engl J Med 2011;365:2453-2462.

24 Carson JL, Sieber F, Cook DR, Hoover DR, Noveck H, Chaitman BR, Fleisher L, Beaupre L, Macaulay W, Rhoads GG, Paris B, Zagorin A, Sanders DW, Zakriya KJ, Magaziner J: Liberal versus restrictive blood transfusion strategy: 3-year survival and cause of death results from the focus randomised controlled trial. Lancet 2014: doi: 10.1016/S0140-6736(14)62286-8.

25 Villanueva C, Colomo A, Bosch A, Concepción M, Hernandez-Gea V, Aracil C, Graupera I, Poca M, Alvarez-Urturi C, Gordillo J, Guarner-Argente C, Santaló M, Muniz E, Guarner C: Transfusion strategies for acute upper gastrointestinal bleeding. N Engl J Med 2013;368:11- 21 .
Walsh TS, Boyd JA, Watson D, Hope D, Lewis S, Krishan A, Forbes JF, Ramsay P, Pearse R, Wallis C, Cairns C, Cole S, Wyncoll D: Restrictive versus liberal transfusion strategies for older mechanically ventilated critically ill patients: a randomized pilot trial. Crit Care Med 2013;41:2354-2363.

27 Robertson CS, Hannay HJ, Yamal JM, Gopinath S, Goodman JC, Tilley BC, Epo Severe TBITI, Baldwin A, Rivera Lara L, Saucedo-Crespo H, Ahmed O, Sadasivan S, Ponce L, Cruz-Navarro J, Shahin H, Aisiku IP, Doshi P, Valadka A, Neipert L, Waguspack JM, Rubin ML, Benoit JS, Swank P: Effect of erythropoietin and transfusion threshold on neurological recovery after traumatic brain injury: a randomized clinical trial. JAMA 2014;312:36-47.

28 Holst LB, Haase N, Wetterslev J, Wernerman J, Guttormsen AB, Karlsson S, Johansson PI, Aneman A Vang ML, Winding R, Nebrich L, Nibro HL, Rasmussen BS, Lauridsen JR, Nielsen JS, Oldner A, Pettila V, Cronhjort MB, Andersen LH, Pedersen UG, Reiter N, Wiis J, White JO, Russell L, Thornberg KJ, Hjortrup PB, Muller RG, Moller MH, Steensen M, Tjader I, Kilsand $\mathrm{K}$, Odeberg-Wernerman S, Sjobo B, Bundgaard H, Thyo MA, Lodahl D, Maerkedahl R, Albeck C, Illum D, Kruse M, Winkel P, Perner A; TRISS Trial Group; Scandinavian Critical Care Trials Group: Lower versus higher hemoglobin threshold for transfusion in septic shock. N Engl J Med 2014;371:1381-1391.

29 Carson JL, Carless PA, Hebert PC: Transfusion thresholds and other strategies for guiding allogeneic red blood cell transfusion. Cochrane Database Syst Rev 2012;4:CD002042.

30 Rohde JM, Dimcheff DE, Blumberg N, Saint S, Langa KM, Kuhn L, Hickner A, Rogers MA: Health careassociated infection after red blood cell transfusion: a systematic review and meta-analysis. JAMA 2014;311: 1317-1326.

31 Hebert PC, Carson JL: Transfusion threshold of $7 \mathrm{~g}$ per deciliter - the new normal. N Engl J Med 2014;371: 1459-1461.

32 Cooper HA, Rao SV, Greenberg MD, Rumsey MP, McKenzie M, Alcorn KW, Panza JA: Conservative versus liberal red cell transfusion in acute myocardial infarction (the CRIT Randomized Pilot Study). Am J Cardiol 2011;108:1108-1111.

33 Goodnough LT, Shieh L, Hadhazy E, Cheng N, Khari P, Maggio P: Improved blood utilization using realtime clinical decision support. Transfusion 2014;54: 1358-1365.

34 Goodnough LT, Maggio P, Hadhazy E, Shieh L, Hernandez-Boussard T, Khari P, Shah N: Restrictive blood transfusion practices are associated with improved patient outcomes. Transfusion 2014;54:2753-2759. 